\title{
Diel feeding of the chaetognath Sagitta enflata in the Zanzibar Channel, western Indian Ocean
}

\author{
Vidar Øresland* \\ Institute of Marine Research, National Board of Fisheries, PO Box 4, 45321 Lysekil, Sweden
}

\begin{abstract}
The diel feeding cycle of Sagitta enflata, the dominant chaetognath in the Indian Ocean, was investigated, using gut content analyses, between the monsoon periods on 2 occasions, October 1995 and May 1996. Zooplankton samples were collected every second hour during a $24 \mathrm{~h}$ period close to a drifting buoy in the middle of the Zanzibar Channel. S. enflata made up $64 \%$ (October) and $77 \%$ (May) of all chaetognaths in this study. S enflata and all chaetognaths contributed as much as 30 and $33 \%$, respectively, of the total $90 \mu \mathrm{m}$ net zooplankton wet weight in October (May samples could not be weighed due to occurrence of phytoplankton). S. enflata fed most actively at night. Small copepods with a mandible width $<0.07 \mathrm{~mm}$ (prosome length $<1 \mathrm{~mm}$ ) were its predominant prey. Feeding rate and mean number of small copepods found in S. enflata were 3 times higher in October than in May. In contrast, the estimated daily predation impact on the standing stock of small copepods (by number) was around $1 \%$ for both periods. This may be a negligible predation effect considering the short life-span of tropical copepods. It is suggested that predation effects are related to temperature, since a similar predation impact may be important in cold polar waters where copepod life-spans are much longer. Daily cannibalistic predation impact (by number) was estimated to be between 1 and $4 \%$ (October) and between 2 and $9 \%$ (May) using assumed maximum and minimum digestion times of 8 and $2 \mathrm{~h}$. Cannibalism, therefore, may be an important source of mortality in $S$. enflata populations.
\end{abstract}

KEY WORDS: Zooplankton · Chaetognatha $\cdot$ Sagitta enflata $\cdot$ Flacisagitta enflata Copepods Feeding · Predation - Cannibalism - Indian Ocean

\section{INTRODUCTION}

The phylum Chaetognatha contains at least 115 species (Bieri 1991). Chaetognaths are found in all oceans, from polar to tropical areas, and from the surface to several thousand meters depth (see reviews by Alvarino 1965, Pierrot-Bults \& Nair 1991). They can make up a large proportion of zooplankton wet weight and are potentially one of the main sources of predation pressure on the copepod community. However, our understanding of chaetognath feeding, its variability, and its consequences for predator and prey population dynamics and production is limited and biased (see reviews by Feigenbaum \& Maris 1984, Feigenbaum 1991).

Most diel feeding studies carried out until now have been limited to a few species in coastal areas. There is a general lack of studies from open oceanic, tropical

•E-mail: v.oresland@imr.se and polar areas, as well as from deep water. In this study, the diel feeding of a chaetognath species was studied through gut content analysis for the first time in the Indian Ocean (to my knowledge). Sagitta enflata, or Flacisagitta enflata (Bieri 1991), is a cosmopolitan species in temperate and warm waters (Alvarino 1965) and occurs mainly in the upper $300 \mathrm{~m}$ (Pierrot-Bults \& Nair 1991). It is the dominant chaetognath species by number in the Indian Ocean (e.g. Furnestin \& Radiguet 1964, Furnestin \& Ducret 1976 , Nair 1977. Andreu et al. 1989, Michel 1995) and its feeding behaviour is therefore of special interest.

The specimens in this study were caught during two $24 \mathrm{~h}$ sampling periods between the monsoon periods, following a drifting buoy in the Zanzibar Channel off Tanzania, East Africa. The diet, diel feeding behaviour, feeding rates and estimates of predation impact on standing stock of copepods - as well as the impact of cannibalism-are presented, and the results compared with data from other oceans. 


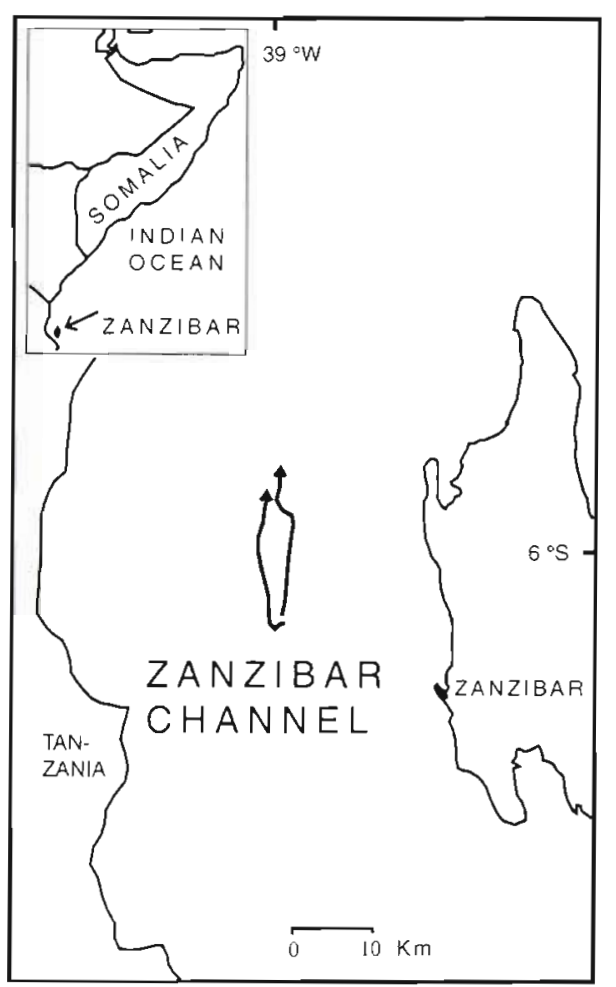

Fig. 1. Sampling area in the Zanzibar Channel and the northward drift of the buoy close to (within 10 to $100 \mathrm{~m}$ ) which zooplankton samples were taken every second hour during two $24 \mathrm{~h}$ sampling programmes (right track $=24$ to 25 October 1995, left track $=27$ to 28 May 1996)

\section{METHODS}

The area. The Zanzibar Channel (Fig. 1) is influenced by the nor theast monsoon from about December to March and by the southeast monsoon from about June to October. Between monsoon periods the sea is relatively calm. The bottom depth in the middle of the channel increases from about $30 \mathrm{~m}$ in the central part to about $80 \mathrm{~m}$ in the northern part. Throughout the year, from the surface to $5 \mathrm{~m}$ above the bottom, the temperature varies around $27^{\circ} \mathrm{C}\left(26\right.$ to $\left.30^{\circ} \mathrm{C}\right)$ and salinity is between 34.5 and 36 psu (Wickstead 1963). Detailed knowledge of the zooplankton community is still lacking from this area, although Wickstead (1963) showed that total zooplankton abundance and biomass in the Zanzibar Channel varies considerably during the year.

Field sampling. Two $24 \mathrm{~h}$ sampling programmes were carried out between the monsoon periods on 24-25 October 1995 and 27-28 May 1996 in the central part of the Zanzibar Channel (Fig. 1). The temperature was $27^{\circ} \mathrm{C}$ (from mercury thermometer readings) in water samples taken every $5 \mathrm{~m}$ from the surface to the bottom ( $35 \mathrm{~m}$ ) at the beginning of both sampling periods. Salinity was not measured. Four zooplankton samples were collected every second hour (a total of 12 sampling times and 48 samples during each $24 \mathrm{~h}$ period), from a $7 \mathrm{~m}$ long open fishing boat, within 10 to $100 \mathrm{~m}$ from a buoy that was drifting in a northward direction. This was done in order to reduce variability in prey and predator abundance and size frequency distribution of organisms compared with sampling carried out at a fixed geographical position.

The buoy (40 cm high) was equipped with a small blinking light so that it could be followed during the night. A nylon parachute $(1.4 \mathrm{~m}$ in diameter) was attached to a rope $5 \mathrm{~m}$ below the buoy, and a $10 \mathrm{~kg}$ weight was attached to the end of the rope $10 \mathrm{~m}$ below the parachute. The positions of the buoy were determined by using a GPS. In May the parachute was entangled during the first hours, and the drift of the buoy was affected by the wind (Fig. 1).

Samples were taken using a WP2 $90 \mu \mathrm{m}$ net (UNESCO 1968). The diameter and the mouth area of the net were $0.57 \mathrm{~m}$ and $0.25 \mathrm{~m}^{2}$, respectively. A calibrated General Oceanics Inc. flowmeter (model 2030) was mounted halfway between the centre of the net opening and the frame. The net was hauled in by hand, with the rope kept as vertical as possible, from 1 to $2 \mathrm{~m}$ above the bottom ( 35 to $50 \mathrm{~m}$ ) to the surface at a speed of approximately $0.5 \mathrm{~m} \mathrm{~s}^{-1}$. Sampling often took less than 2 min and always less than 3 min. All zooplankton samples were preserved within 2 min in $5 \%$ formaldehyde in seawater buffered with borax.

Laboratory methods. For each sampling time, between 1 and 4 zooplankton samples were sorted for all chaetognaths (all species) depending on the number of Sagitta enflata in the samples. I wanted a minimum of $150 \mathrm{~S}$. enflata individuals from each sampling time. The number of $S$. enflata sorted and analysed for each sampling time ranged from 147-358 in October to 164-623 in May. All chaetognaths appeared to be in good condition, with most of the fragile fins intact. Species identification of $S$. enflata was made according to descriptions given in Bieri (1991), George (1952) and Lutschinger (1993). Only individuals that were 4 mm or longer could be identified. Shorter individuals were regarded as belonging to a group called 'other chaetognaths', which may have contributed to an underestimation of numbers of $S$. enflata.

Wet weight was determined for Sagitta enflata, other chaetognaths, and remaining zooplankton found in the analysed October samples according to procedures given in Oresland (1990). Chaetognaths were the only large $(>1 \mathrm{~cm})$ organisms that occurred in the samples. The May zooplankton samples were not weighed due to the presence of dense concentrations of phytoplankton. 
Lengths of Sagitta enflata individuals were measured (after 6 to $18 \mathrm{mo}$ in formaldehyde) to the nearest $\mathrm{mm}$, under a stereomicroscope (see Conway \& Robins 1991 for the effects of formaldehyde preservation on chaetognath length). Body length was measured from the anterior tip of the head to the end of the tail, excluding the tail fin. Maturity stages of $S$. enflata were classified according to the development of the ovaries (Zo 1973) as follows: Stage 1, no visible ovaries; Stage 2, ovaries visible, no mature ovum; Stage 3, 1 or more mature ovum. Individuals at Stage 3 could have been reproducing.

The microdissection technique and the analyses of chaetognath gut content-which was inferred from identification of prey mandibles, chaetognath hooks, and other hard or special prey parts-followed the same procedure as in Øresland (1987). I used tungsten needles $(0.1$ to $0.3 \mathrm{~mm}$ in diameter, sharpened in melted $\mathrm{NaNO}_{2}$ ) and polyvinyl-lactophenol (poisonous, ventilation was needed) as a dissecting fluid. Insect pins are too coarse and should not be used for this kind of microdissection. The prey items were divided into the following taxonomic categories: small copepods (mandible width $<0.07 \mathrm{~mm}$, prosome length $<1 \mathrm{~mm}$ ), large copepods, appendicularians, chaetognaths and unidentified. Only completely swallowed prey items were included in the analyses.

Feeding rates (FR) were estimated using Bajkov (1935).

$$
\mathrm{FR}=\frac{\text { mean } \mathrm{NPC}}{\text { digestion time }(\mathrm{h})} \times 24
$$

where FR = daily feeding rate (mean number of prey taken per $24 \mathrm{~h}$ ) and mean NPC = mean number of prey per carnivore per $24 \mathrm{~h}$. Mean NPC was calculated as the mean of the NPC estimates for the 12 different sampling times. This method could be used, because all samples were taken at equal time increments during both $24 \mathrm{~h}$ periods. Estimates of digestion time for prey of Sagitta enflata are not available from the Indian Ocean. I therefore assumed a digestion time of $2 \mathrm{~h}$, which is intermediate between published values of about 1 h (Szyper 1978, Kimmerer 1984) and slightly over 3 h (Feigenbaum 1979) (see 'Discussion').

Predation impact was calculated as (FR $\times$ no. Sagitta enflata/no. copepods) $\times 100$ to give the proportion (in \%) of standing stock of copepods (by numbers) taken during a $24 \mathrm{~h}$ period. The zooplankton samples, from which the chaetognaths had been removed for analysis, were combined from each $24 \mathrm{~h}$ period. The abundance of copepods found in each of these 2 zooplankton mixtures was then estimated by counting specimens from subsamples obtained using a Motoda box (Motoda 1959) and Kott's plankton splitter (Kott 1953). Eight independent subsamples (each $1 / 2000$ of mixture in October and 1/4000 of mixture in May) were taken from each mixture. Subsequent counts of the last 4 subsamples did not change the estimated abundance by more than $3 \%$. Plots of standard error (SE) against the number of subsequent subsamples showed that the last subsamples only contributed to a minor decrease in SE (not shown, standard deviation [SD] is given in Table 2).

\section{RESULTS}

\section{Abundance and size distribution}

In this study, Sagitta enflata was by far the most common chaetognath by number. The mean proportion of $S$. enflata to all chaetognaths was $64 \%(\mathrm{SD}=10, \mathrm{n}=$ 12 ) in October, and $77 \%(\mathrm{SD}=6, \mathrm{n}=12$ ) in May (calculated as the mean of the estimates for the 12 different sampling times. The number of $S$. enflata $\mathrm{m}^{-3}$ was $17(\mathrm{SD}=8, \mathrm{n}=12)$ in October and $31(\mathrm{SD}=18, \mathrm{n}=11)$ in May (1 flowmeter reading missing in May). $S$. enflata alone contributed $30 \%(\mathrm{SD}=13, \mathrm{n}=12)$ and all chaetognaths contributed $33 \%(\mathrm{SD}=13, \mathrm{n}=12)$ of the total $90 \mu \mathrm{m}$ net zooplankton wet weight in October. The mean number of copepods per $\mathrm{m}^{3}$ was 9054 and 4744 in October and May, respectively, calculated as the estimated total number of copepods in the zooplankton samples from which $S$. enflata were sorted (see Table 2) divided by the estimated total volume of water filtered ( 185 and $129 \mathrm{~m}^{3}$ ).

There was a clear difference in size and maturitystage distribution of Sagitta enflata between the two $24 \mathrm{~h}$ sampling periods (Fig. 2). Variation in the distribution within each $24 \mathrm{~h}$ period was negligible. The total size range and median were 4 to $18 \mathrm{~mm}$ and $9 \mathrm{~mm}$ in October, and 4 to $16 \mathrm{~mm}$ and $5 \mathrm{~mm}$ in May. S. enflata individuals less than $4 \mathrm{~mm}$ were not identified to species level.

\section{Feeding}

Small copepods were the most abundant prey in both October and May (Table 1). Common copepod genera found in the guts included e.g. Oithona, Oncaea and Paracalanus. Small copepods occurred in the guts (in October and May, respectively) as single prey ( 65 and $85 \%$ ), double prey (21 and $14 \%$ ) and multiple prey $(13$ and $2 \%)$. Almost all prey items from the other prey categories occurred as single prey. The unidentified prey items did not contain exoskeleton parts from copepods. Only 1 fish larva, unidentified and somewhat digested, was found in this study (in the gut of a $7 \mathrm{~mm}$ long Sagitta enflata in May). 


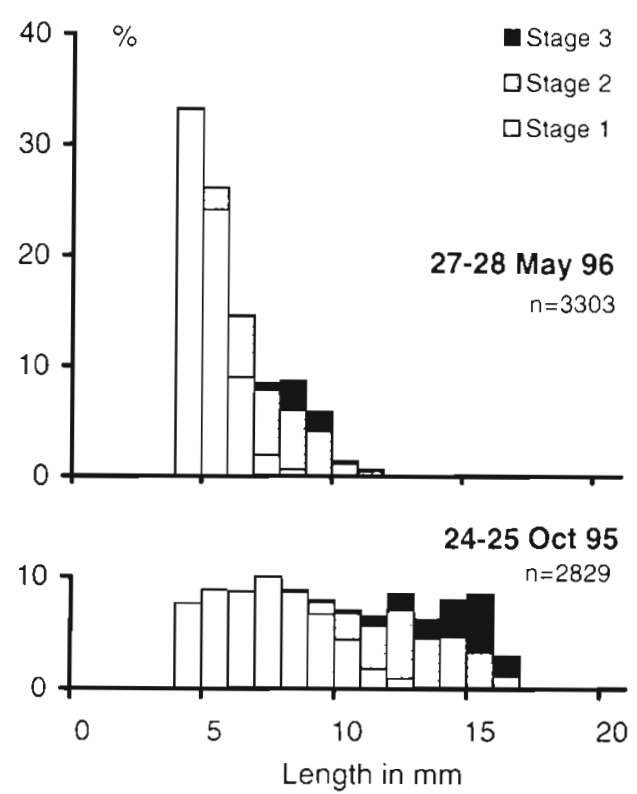

Fig. 2. Sagitta enflata. Length-frequency and maturity stage distribution in the Zanzibar Channel. Individuals less than $4 \mathrm{~mm}$ long are not included and size classes consisting of individuals making up less than $1 \%$ of the total sample size are not shown. For definition of Stages 1 to 3, see 'Methods'

There was a sharper increase in feeding on small copepods during the night in October than in May (Fig. 3), although the dark period is similar for both months. Mean NPC estimates for small copepods, plotted versus Sagitta enflata length, show no clear trends for either October or May, and are therefore not shown.

The estimates of mean NPC, feeding rate and predation impact on small copepods over $24 \mathrm{~h}$ are shown in Table 2. The October data are divided into 2 size groups. The median of the smaller size group is $7 \mathrm{~mm}$, which is close to the $5 \mathrm{~mm}$ median of the May data. The size frequency distributions, however, were quite different (Fig. 2). Mean NPC estimates were more than 3 times higher in October than in May. The FR estimates differed in the same way, since the same digestion time was used for all 4 estimates.
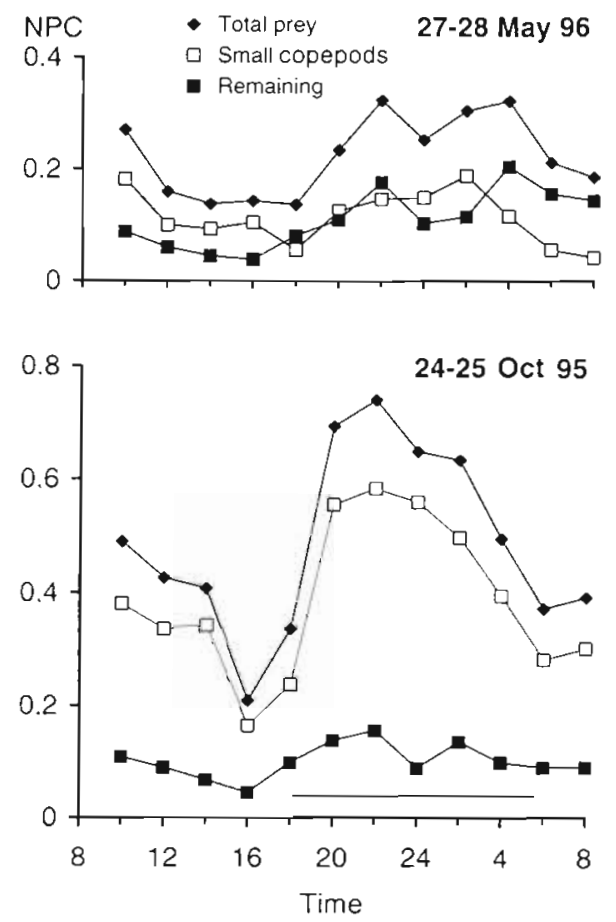

Fig. 3. Sagitta enflata. Number of prey per carnivore (NPC) during two $24 \mathrm{~h}$ periods in the Zanzibar Channel. Small copepods include all copepodites with a mandible width less than $0.07 \mathrm{~mm}$. The category 'Remaining' includes larger copepodites and all other prey items, including unidentified prey items. The number of prey items found is given in Table 1 and mean NPC estimates for the 2 sampling periods are given in Table 2. The solid horizontal line indicates the dark period between sunset and sunrise in October and May

The predation impact on small copepods for October and May were similar $(<1 \%)$. Copepods in subsamples were not separated into small and large copepods, since the small copepods totally dominated the samples. Therefore, the numbers of small copepods were overestimated, and the predation impact on them was underestimated.

The cannibalistic impact per 24 h on Sagitta enflata standing stock (by numbers) was calculated using digestion times of 8 and $2 \mathrm{~h}$ (assumed maximum and

Table 1. Number of Sagitta enflata analysed, percentage $S$. enflata with gut content, number of prey items found, and percentage distribution of prey categories

\begin{tabular}{|c|c|c|c|c|c|c|c|c|}
\hline & $\begin{array}{l}\text { Sagitta } \\
\text { enflata }\end{array}$ & $\begin{array}{l}\% \text { S. enflata } \\
\text { with food }\end{array}$ & $\begin{array}{c}\text { Small } \\
\text { copepods }\end{array}$ & $\begin{array}{l}\text { Large } \\
\text { copepods }\end{array}$ & $\begin{array}{l}\text { Appendi- } \\
\text { cularians }\end{array}$ & $\begin{array}{l}\text { Chaeto- } \\
\text { gnaths }\end{array}$ & $\begin{array}{l}\text { Uniden- } \\
\text { tified }\end{array}$ & $\begin{array}{l}\text { Total } \\
\text { prey }\end{array}$ \\
\hline $24-25$ Oct 95 & 2829 & $37 \%$ & $\begin{array}{l}1041 \\
79 \%\end{array}$ & $\begin{array}{l}\overline{7} 1 \\
5 \%\end{array}$ & $\begin{array}{l}67 \\
5 \%\end{array}$ & $\begin{array}{r}9 \\
1 \%\end{array}$ & $\begin{array}{l}122 \\
9 \%\end{array}$ & 1310 \\
\hline 27-28 May 96 & 3303 & $11 \%$ & $\begin{array}{r}407 \\
54 \%\end{array}$ & $\begin{array}{c}30 \\
4 \%\end{array}$ & $\begin{array}{l}22 \\
3 \%\end{array}$ & $\begin{array}{l}24 \\
3 \%\end{array}$ & $\begin{array}{l}266 \\
36 \%\end{array}$ & 749 \\
\hline
\end{tabular}


Table 2. Sagitta enflata. Mean number of prey per carnivore (mean NPC), feeding rate (FR) as number of small copepods taken, number of $S$. enflata analysed, and predation impact as daily proportion (\%) taken of standing stock of small copepods in the Zanzibar Channel (all during $24 \mathrm{~h}$ ). See 'Methods' for calculation formulas. Digestion time for a small copepod is assumed to be $2 \mathrm{~h}$. The estimated numbers of copepods in the samples from which $S$. enflata were sorted were $1675000(\mathrm{n}=8, \mathrm{SD}=315278$, $\mathrm{CV}=19 \%)$ and $612000(\mathrm{n}=8, \mathrm{SD}=54845, \mathrm{CV}=9 \%)$ in October and May, respectively

\begin{tabular}{|lcccccc}
\hline & Small copepods & $\begin{array}{c}\text { Mean NPC } \\
\text { Remaining }\end{array}$ & Total prey & FR & $\begin{array}{c}\text { No. of } \\
\text { S. enflata }\end{array}$ \\
\hline 24-25 Oct 95 & & & & & & \\
4-10 mm S. enflata & 0.37 & 0.05 & 0.42 & 4.44 & 1667 & 0.44 \\
11-18 mm S. enflata & 0.42 & 0.17 & 0.59 & 5.04 & 1162 & 0.35 \\
All size classes & 0.39 & 0.10 & 0.49 & 4.68 & 2829 & 0.79 \\
27-28 May 96 & 0.11 & 0.11 & 0.22 & 1.32 & 3303 & 0.71 \\
All size classes & & & & & \\
\hline
\end{tabular}

minimum values, see 'Discussion') to be 1 and $4 \%$ in October and 2 and $9 \%$ in May. This assumes that those chaetognath hooks similar in appearance to $S$. enflata hooks found in the guts all came from $S$. enflata individuals, and the mean NPC calculated as no. prey chaetognaths/no. S. enflata (using data from Table 1).

\section{DISCUSSION}

\section{Methods}

Factors and assumptions that will bias a representative collection of predators and prey, gut content, analyses of gut content, estimates of mean NPC, digestion times, feeding rates and predation impact on prey categories have been discussed by Feigenbaum \& Maris (1984), Feigenbaum (1991), Øresland (1987), Baier \& Purcell (1997a) and others. In this study it was assumed that the $90 \mu \mathrm{m}$ net sampled all analysed size classes of Sagitta enflata and other chaetognaths equally well. However, phytoplankton clogged the net in May, which may have affected the selectivity of the net. The $90 \mu \mathrm{m}$ net samples may have led to an underestimation of the smallest copepodites and especially the copepod nauplii, but nauplii were not common prey items in this study. Hopcroft et al. (1998a) concluded that all nauplii, most copepodites and many adults were missed by a $200 \mu \mathrm{m}$ plankton net (compared to a $64 \mu \mathrm{m}$ plankton net) used in Kingston Harbour, Jamaica. The short hauling time and the short time before preservation in this study is assumed to have limited both potential feeding and prey loss in the net (Baier \& Purcell 1997a). In addition, only completely swallowed prey items were included in the analyses which further limited the risk of overestimating NPC.

As long as only approximate digestion time estimates exist for chaetognaths, our knowledge of chaetognath feeding rates will be limited and compar- isons between different studies will remain difficult. There is a need for more accurate chaetognath digestion time estimates for a variety of different feeding situations. It is not yet possible to say whether the digestion time estimates used in this study were too low or too high, but the feeding rate estimates presented here could easily be recalculated (using the data given in Tables 1 \& 2) if more accurate digestion time data become available. It should be noted that the water temperature $\left(27^{\circ} \mathrm{C}\right.$ throughout the water column on both sampling periods) was higher than the $23^{\circ} \mathrm{C}$ used in the digestion time experiments of Feigenbaum (1979), indicating that a digestion time of $3 \mathrm{~h}$ might be too long. However, there are many other factors (e.g. number, size and type of prey, chemical composition, size and maturity condition of predator etc.) that might potentially affect digestion time.

\section{Abundance and wet weight proportion}

The high proportion of Sagitta enflata relative to all chaetognaths (64 and $77 \%$ in October and May, respectively), is consistent with results from other studies in the Indian Ocean (see 'Introduction'). There is, however, a lack of quantitative abundance estimates (using calibrated flowmeters) for $S$. enflata in the Indian Ocean and elsewhere. The concentrations of $S$. enflata (17 to $31 \mathrm{~m}^{-3}$ ) reported here are, however, comparable to the estimates (approximately 12 to $38 \mathrm{~m}^{-3}$ ) given in Baier \& Purcell (1997b, their Fig. 2A) for the coastal waters off North Carolina, USA, where S. enflata was also the most abundant chaetognath. Øresland (1995) reported that the chaetognath Eukrohnia hamata contributed up to $20 \%$ of zooplankton wet weight in Gerlache Strait, Antarctic Peninsula, which is lower than the $33 \%$ reported in this study. However, relative abundance and wet weight proportions of chaetognaths to total zooplankton may vary considerably on both temporal and spatial scales (e.g. Øresland 1983, Pakhomov 
et al. 1999). Thus, all estimates in this and other studies, which are based on limited temporal and geographical predator and prey abundance data, should be interpreted and compared with caution.

\section{Feeding}

The NPC curves in Fig. 3 show the importance of frequent sampling in order to discover peaks in feeding intensity and in estimating the mean NPC for the two $24 \mathrm{~h}$ periods. The enhanced feeding of Sagitta enflata at night is consistent with results from Hawaii (Szyper 1978, Kimmerer 1984) and Guanabara Bay, Brazil (Marazzo et al. 1997), although Terazaki (1996) found that the proportion of $S$. enflata with food in the gut increased during the night until noon in the Central Equatorial Pacific.

The fact that mean NPC estimates for small copepods were more than 3 times higher in October compared to May in this study could have several explanations. High concentrations of phytoplankton and lower mean concentration of small copepods compared to October might have affected prey encounter rates in May. Another explanation might be that in May noncopepod prey made up $50 \%$ of the total NPC (although total mean NPC was still lower in May). However, in short $24 \mathrm{~h}$ studies where the immediate pre-feeding history is unknown, NPC comparisons like this (and comparisons with results from other areas) should be interpreted with caution. Szyper (1978) and Kimmerer (1984) reported total FR estimates of 7.4 prey $d^{-1}$ and 10 to 12 prey $\mathrm{d}^{-1}$, respectively, in Kaneohe Bay, Hawaii, which is 2 to 3 times higher than was found in October in this study. However, the DT estimate used in the FR calculations in Szyper (1978) and Kimmerer (1984) was only $1 \mathrm{~h}$. If a DT of $2 \mathrm{~h}$ had been applied, then FR estimates would have been similar to the October estimates in this study. Terazaki (1996) estimated a total FR of 1.81 prey $\mathrm{d}^{-1}$. This is similar to the May estimates in this study.

At population level, a predation impact of about $1 \%$ $\mathrm{d}^{-1}$ of the small copepods (by numbers) is negligible in tropical waters, if total copepodite development time is as short as 4 to $5 \mathrm{~d}$ (Hopcroft et al 1998b) with little variability throughout the year. In contrast, a similar predation impact could be important in cold polar waters (Oresland 1995) where the life-spans of copepods are often 1 yr or longer. This indicates that predation effects are related to temperature. However, our knowledge of the temporal and geographical variability in life-span, reproduction rate and potential for population increase for small tropical copepods is still limited. So the possibility that cumulative predatory impact might be significant at some times in some areas should not be ruled out. Although temperature is more or less constant throughout the year, zooplankton productivity may show high variability in this monsoon area (Wickstead 1963) and is indicated by the differences in abundance of copepods and chaetognaths, and size frequency distribution of Sagitta enflata seen here.

\section{Cannibalism}

On the basis of 8 reported studies, Feigenbaum (1991) estimated that cannibalistic prey averaged $9.5 \%$ in the diet of Sagitta enflata. In this study, chaetognaths made up 1 to $3 \%$ of the prey items found. Percentage comparisons like this may be biased by different abilities in detecting small prey remnants (e.g. copepod mandibles that are easily missed when using insect pins instead of tungsten needles, inappropriate dissecting fluids, or by using ordinary microscopes instead of high quality inverted microscopes). The 4 cannibalistic impact estimates in this study ranged between 1 and $9 \% \mathrm{~d}^{-1}$ (by numbers) of standing stock (using a digestion time of 8 and 2 h). These estimates suggest that cannibalism could potentially reduce the $S$. enflata population. It is notable that cannibalism was more frequent during May, a period when concentrations of small $S$. enflata were high compared to October. Øresland (1987) found high cannibalistic impact on $S$. setosa during the breeding period when small $S$. setosa were abundant and it was suggested that cannibalism contributed to a sharp decrease in numbers of $S$. setosa at that time. This indicates that it is important to consider the size frequency distributions of chaetognath populations when discussing cannibalistic feeding behaviour.

Acknowledgements. This research was supported financially by SIDA/Sarec, Sweden, contract no. SWE-95-193. I thank the Institute of Marine Sciences (IMS), Zanzibar, for logistic support, B. R. Malisa and S. C. Nguzo at IMS for assistance during sampling, and Peter Ward for reviewing the English.

\section{LITERATURE CITED}

Alvarino A (1965) Chaetognaths. Oceanogr Mar Biol Annu Rev 3:115-194

Andreu P, Marrase C, Berdalet E (1989) Distribution of epiplanktonic Chaetognatha along a transect in the Indian Ocean. J Plankton Res 11:185-192

Baier CT, Purcell JE (1997a) Effects of sampling and preservation on apparent feeding by chaetognaths. Mar Ecol Prog Ser 146:37-42

Baier CT, Purcell JE (1997b) Trophic interactions of chaetognaths, larval fish, and zooplankton in the South Atlantic Bight. Mar Ecol Prog Ser 146:43-53 
Bajkov AD (1935) How to estimate the daily food consumption of fish under natural conditions. Trans Am Fish Soc 65: $288-289$

Bieri R (1991) Systematics of the Chaetognatha. In: Bone $Q$, Kapp H, Pierrot-Bults AC (eds) The biology of the chaetognaths. Oxford University Press, Oxford, p 122-136

Conway DVP, Robins DB (1991) Collection and chemical analysis of chaetognaths and changes due to preservation. In: Bone $\mathrm{Q}, \mathrm{Kapp} \mathrm{H}$, Pierrot-Bults $\mathrm{AC}$ (eds) The biology of the chaetognaths. Oxford University Press, Oxford, p $137-146$

Feigenbaum D (1979) Daily ration and specific daily ration of the chaetognath Sagitta enflata. Mar Biol 54:75-82

Feigenbaum D (1991) Food and feeding behaviour. In: Bone Q. Kapp $H$, Pierrot-Bults AC (eds) The biology of the chaetognaths. Oxford University Press, Oxford, p 45-54

Feigenbaum DL, Maris RC (1984) Feeding in the Chaetognatha. Oceanogr Mar Biol Annu Rev 22:343-392

Furnestin ML, Ducret F (1976) Les Chaetognathes des Séchelles. Rev Zool Afr 90:89-117

Furnestin ML, Radiguet J (1964) Chaetognathes de Madagascar (Secteur de Nosy-Bé). Cah. ORSTOM Ser Oceanogr 2: $55-98$

George PC (1952) A systematic account of the Chaetognatha of the Indian coastal waters, with observations on their seasonal fluctuations along the Malabar coast. Proc Nat Inst Sci India 18:657-689

Hopcroft RR, Roff JC, Lombard D (1998a) Production of tropical copepods in Kingston Harbour, Jamaica: the importance of small species. Mar Biol 130:593-604

Hopcroft RR, Roff JC, Webber MK, Witt JDS (1998b) Zooplankton growth rates: the influence of size and resources in tropical marine copepodites. Mar Biol 132:67-77

Kimmerer WJ (1984) Selective predation and its impact on prey of Sagitta enflata (Chaetognatha). Mar Ecol Prog Ser $15: 55-62$

Kott P (1953) Modified whirling apparatus for the subsampling of plankton. Aust J Mar Res 4:387-393

Lutschinger S (1993) The marine fauna of New Zealand: Chaetognatha (arrow worms). NZ Oceanogr Inst Mem 101

Marazzo A, Machado CF, Nogueira CSR (1997) Notes on feeding of Chaetognatha in Guanabara Bay, Brazil. J Plankton Res 19:819-828

Editorial responsibility: Otto Kinne (Editor), Oldendorf/Luhe, Germany
Michel HB (1995) The chaetognath Aidanosagitta bedfordil (Doncaster 1903) in the Persian Gulf. Bull Mar Sci 56 $490-494$

Motoda S (1959) Devises of simple plankton apparatus. Mem Fac Fish Hokkaido Univ 7:73-94

Nair VR (1977) Chaetognaths of the Indian Ocean. Proc Symp Warm Water Zoopl. Spec PublUNESCO/NIO, Goa, p $168-195$

Øresland V (1983) Abundance, breeding and temporal size distribution of the chaetognath Sagitta setosa in the Kattegat. J Plankton Res 5:425-439

Øresland V (1987) Feeding of the chaetognaths Sagitta elegans and $S$. setosa at different seasons in Gullmarsfjorden, Sweden. Mar Ecol Prog Ser 39:69-79

Dresland V (1990) Feeding and predation impact of the chaetognath Eukrohnia hamata in Gerlache Strait. Antarctic Peninsula. Mar Ecol Prog Ser 63:201-209

Øresland V (1995) Winter population structure and feeding of the chaetognath Eukrohnia hamata and the copepod Euchaeta antarctica in Gerlache Strait, Antarctic Peninsula. Mar Ecol Prog Ser 119:77-86

Pakhomov EA, Perissinotto R, Froneman PW (1999) Predation impact of carnivorous macrozooplankton and micronecton in the Atlantic sector of the Southern Ocean. J Mar Syst 19:47-64

Pierrot-Bults AC, Nair VR (1991) Distribution patterns in Chaetognatha. In: Bone Q, Kapp H, Pierrot-Bults AC (eds) The biology of the chaetognaths. Oxford University Press, Oxford, p 86-116

Szyper JP (1978) Feeding rate of the chaetognath Sagitta enflata in nature. Estuar Coast Mar Sci 7:567-575

Terazaki M (1996) Vertical distribution of pelagic chaetognaths and feeding of Sagitta enflata in the Central Equatorial Pacific. J Plankton Res 18:673-682

UNESCO (1968) Zooplankton sampling. In: Tranter DJ (ed) Monogr Oceanogr Methodol

Wickstead JH (1963) Estimates of total zooplankton in the Zanzibar area of the Indian Ocean with a comparison of the results with two different nets. Proc Zool Soc Lond 141: $577-608$

Zo Z (1973) Breeding and growth of the chaetognath Sagitta elegans in Bedford Basin, Nova Scotia. Limnol Oceanogr $18: 750-756$

Submitted: July 1, 1999; Accepted: October 12, 1999

Proofs received from author(s): January 11, 2000 